\title{
PENGEMBANGAN PERANGKAT PEMBELAJARAN MENGGUNAKAN PENDEKATAN PENDIDIKAN MATEMATIKA REALISTIK UNTUK PESERTA DIDIK KELAS IV
}

\author{
Aljufri Mardi ${ }^{1}$, Sehatta Saragih ${ }^{2}$, Yenita Roza ${ }^{3}$ \\ 1,2,3 Program Pasca Sarjana Pendidikan Matematika, Universitas Riau, Jl. H. R. Soebrantas, Riau \\ Aljufri.mardi7366@grad.unri.ac.id
}

\begin{abstract}
This study aims to develop learning tools using a realistic mathematics education approach that is tested for validity and practicality for grade IV students in the form of syllabus, lesson plans, and LKPD. This type of research is a 4D model development research consisting of defining, designing, developing, and disseminating. Due to time constraints, this research was only carried out until the develop stage. Trials are carried out in two stages, namely expert trials and small group trials. The test subjects in this study were 8 class IV students. The instrument used consisted of a validation sheet to the experts and a student questionnaire response sheet. The results showed that the learning tools developed had fulfilled aspects of validity and practicality. (1) the validity results show that the learning tools developed in the category are very valid with a value in the syllabus of 88.54, in the RPP of 90.57, in the LKPD of 89.01, in the question instrument of 89.58, (2) results small group trials show the mathematics learning device developed in the very practical category of 90.63.
\end{abstract}

Keywords: Development, Learning Tools, PMR

\begin{abstract}
Abstrak
Penelitian ini bertujuan untuk mengembangkan perangkat pembelajaran menggunakan pendekatan pendidikan matematika realistik yang teruji validitas dan kepraktisan untuk peserta didik kelas IV berupa silabus, RPP, dan LKPD. Jenis penelitian ini adalah penelitian pengembangan model 4D yang terdiri atas pendefinisian (define ), perancangan (design), pengembangan (develop), dan penyebaran (disseminate). Karena keterbatasan waktu, penelitian ini hanya dilakukan sampai tahap pengembangan (develop). Ujicoba dilaksanakan dua tahap, yaitu ujicoba ahli dan ujicoba kelompok kecil. Subjek ujicoba dalam penelitian ini adalah 8 orang peserta didik kelas IV. Instrumen yang digunakan terdiri atas lembar validasi kepada ahli dan lembar angket respon peserta didk. Hasil penelitian menunjukkan bahwa perangkat pembelajaran yang dikembangkan telah memenuhi aspek validitas dan kepraktisan. (1) hasil validitas menenunjukkan bahwa perangkat pembelajaran yang dikembangkan pada kategori sangat valid dengan nilai pada silabus sebesar 88,54, pada RPP sebesar 90,57, pada LKPD sebesar 89,01, pada instumen soal sebesar 89,58, (2) hasil ujicoba kelompok kecil menunjukkan perangkat pembelajaran matematika yang dikembangkan pada kategori sangat praktis sebesar 90,63.
\end{abstract}

Kata kunci: Pengembangan, Perangkat Pembelajaran, PMR

\section{PENDAHULUAN}

Kurikulum 2013 yang terbaru saat ini merupakan langkah lanjutan pengembangan Kurikulum Berbasis Kompetensi (KBK) yang telah dirintis pada tahun 2004 dan Kurikulum Tingkat Satuan Pendidikan (KTSP) tahun 2006. Kurikulum 2013 berusaha untuk menanamkan nilai sikap, nilai pengetahuan, dan nilai keterampilan secara terpadu untuk setiap satuan pendidikan. Nilai tersebut dapat diperoleh peserta didik melalui proses pembelajaran. Dalam permendikbud Nomor 22 Tahun 2016 tentang Standar Proses Pendidikan Dasar dan Menengah dinyatakan bahwa proses pembelajaran dilaksanakan secara interaktif, inspiratif, menyenangkan, menantang, memotivasi peserta didik untuk berpartisipasi aktif, serta memberikan ruang yang cukup bagi prakarsa, kreativitas, dan kemandirian sesuai dengan bakat, minat, dan perkembangan fisik serta psikologis peserta didik.

Pembelajaran dalam kurikulum 2013 memberikan kesempatan kepada peserta didik untuk 
mengembangkan potensi, minat, dan bakat untuk mencapai tujuan (Kementerian Pendidikan dan Kebudayaan, 2017). Kemampuan berpikir peserta didik harus dikembangkan untuk memahami matematika dengan benar (Heleni \& Zulkarnain, 2018) Tujuan pembelajaran matematika yang tercantum dalam Kurikulum 2013 salah satunya adalah pemecahan masalah matematis. Pemecahan masalah matematis didefinisikan sebagai area psikologi kognitif yang berhubungan dengan proses dalam memecahkan masalah (Pal \& Poyen, 2017). Pemecahan masalah dipandang sebagai suatu proses atau cara yang dilakukan seseorang untuk menyelesaikan masalah matematis berdasarkan data dan informasi yang diketahui dengan menggunakan konsep matematika (Sundayana, 2016).

Hasil survei yang dilakukan oleh TIMSS (Trends in International Mathematics and Science Study) pada tahun 2011 yang dikoordinasikan oleh IEA (The International Association for the Evaluation of Educational Achievement), dengan indikator kognitif yang dinilai oleh TIMSS terlihat bahwa kemampuan pemecahkan masalah peserta didik masih tergolong rendah. Hasil menunjukkan bahwa Indonesia menempati peringkat 38 dari 45 negara dengan nilai rata-rata 386 dari nilai standar yang ditetapkan yaitu 500 (Ratnasari \& Ratu, 2017).

Survei serupa dilakukan oleh PISA (Programme for International Student Assesment) yang diselenggarakan oleh OECD (Organization for Economic Coorperation and Development) pada tahun 2012. Hasil survei menunjukkan bahwa Indonesia menempati peringkat ke 64 dari 65 negara dengan nilai rata-rata 375 dari nilai standar 500 (Ratnasari \& Ratu, 2017). Sejalan dengan hasil survei tersebut, hasil pra penelitian menunjukkan kemampuan pemecahan masalah matematis peserta didik kelas IV SD Islam Plus YLPI Pekanbaru pada materi keliling dan luas bangun datar masih tergolong rendah. Persentase peserta didik melakukan kesalahan pada setiap indikator KPMM dapat dilihat pada Tabel 1. berikut.

Tabel 1.

Persentase kesalahan berdasarkan indikator KPMM.

\begin{tabular}{|l|c|}
\hline \multicolumn{1}{|c|}{ Indikator KPMM Peserta Didik } & Persentase Kesalahan \\
\hline Kemampuan memahami masalah & $50,72 \%$ \\
\hline Kemampuan merencanakan pemecahan masalah & $53,62 \%$ \\
\hline Kemampuan menyelesaikan rencana pemecahan masalah & $71,01 \%$ \\
\hline Kemampuan memeriksa kembali jawaban & $65,22 \%$ \\
\hline
\end{tabular}

Tabel 1. menunjukkan bahwa persentase peserta didik melakukan kesalahan pada setiap indikator KPMM sangat tinggi. Pernyataan tersebut didukung dengan hasil kerja peserta didik dalam menyelesaikan sebuah soal KPMM. Dari soal yang diberikan guru, peserta didik dapat menuliskan apa yang diketahui namun masih kurang jelas dan tidak lengkap dalam menguraikannya. Urutan langkah rencana pemecahan masalah tidak terurut dengan baik dan tidak lengkap. Peserta didik tampak belum mampu menyelesaikan rencana pemecahan masalah. Peserta didik tidak menuliskan kesimpulan jawaban. Hal ini menunjukkan KPMM peserta didik masih sangat rendah.

Fakta di atas menunjukkan bahwa kemampuan peserta didik dalam memecahkan masalah 
belum optimal. Disatu sisi kemampuan pemecahan masalah menjadi tujuan pokok konteks matematika. Salah satu faktor penyebab rendahnya kemampuan pemecahan masalah matematis peserta didik adalah karena kurangnya penekanan dalam proses pembelajaran baik ketersediaan sumber belajar maupun fasilitas yang disediakan guru (Apriyani, Sehatta Saragih, 2018). Kemampuan pemecahan masalah matematis dapat dicapai peserta didik dengan menerapkan model atau pendekatan pembelajaran yang memberikan kesempatan kepada peserta didik untuk mengembangkan aktivitas belajarnya dengan cara-cara informal menuju cara yang formal. Salah satu pendekatan pembelajaran yang dapat dijadikan alternatif dalam proses Pendidikan Dasar dan Menengah adalah pendekatan pendidikan matematika realistik (PMR).

Ramadhani (dalam Sugianto, Roza, Y., 2020) menjelaskan pendekatan PMR menuntut siswa untuk mengkontruksi pengetahuan dengan kemampuannya sendiri melalui aktivitas-aktivitas yang dilakukannya dalam kegiatan pembelajaran. Pendekatan PMR menekankan pada keterampilan proses matematika, berdiskusi dan berkolaborasi, beragumentasi dengan teman sekelas sehingga mereka dapat menemukan sendiri dan akhirnya menggunakan matematika untuk menyelesaikan masalah baik secara individu maupun kelompok. Pendapat lain menyebutkan bahwa, pendekatan matematika realistik merupakan pendekatan pembelajaran yang berorientasi pada penalaran siswa dalam menyelesaikan masalah yang bersifat realistik yang ditujukan untuk mengembangkan pola pikir praktis, logis, kritis, dan jujur (Daitin Tarigan, 2006).

Pendidikan Matematika Realistik (PMR) adalah pendekatan yang dipandang sejalan dan sesuai dengan usia siswa SD yaitu 7-12 tahun yang berada pada perkembangan kognitif operasional konkret. Siswa SD masih terkait dengan objek nyata sehingga dapat ditangkap oleh panca indra (Heruman, 2014). Pendekatan ini menekankan pada belajar penemuan, yaitu siswa dapat menyusun dan menemukan konsep. Sesuai dengan pendapat Van den Heuvel-Panhuizen (1996) bahwa PMR membantu siswa untuk berperan aktif dalam menemukan atau menyusun pengetahuannya sendiri. PMR sangat sesuai dengan era pembelajaran sekarang yaitu belajar konstruktivis. Siswa memiliki peran aktif pada kegiatan pembelajaran sehingga pembelajaran lebih bermakna.

Menurut teori Piaget anak usia SD termasuk pada tahap operasional konkret. Teori Piaget ini sejalan dengan pendekatan matematika realistik karena pembelajarannya menggunakan konteks yang berasal dari lingkungan siswa. Konteks yang disajikan bisa berupa masalah, permainan, bahkan berupa benda konkret yang dapat dimanipulasi oleh siswa secara langsung. Dengan demikian siswa akan lebih mudah dalam memahami konsep yang dijelaskan.

Susana \& Zubir (2015) menyatakan bahwa ada beberapa prinsip yang merupakan dasar teoritis PMR antara lain: a) Prinsip Guided Reinvention dan Progressive Mathematization; Prinsip Guided Reinvention ialah penekanan pada "penemuan kembali" secara terbimbing. b) Prinsip Progressive Mathematization adalah upaya yang yang mengarahkan ke pemikiran matematis yaitu matematika horizontal ke matematika vertikal. c) Fenomenologi Didaktis (Didactical Phenomenology); Prinsip ini 
menekankan fenomena pembelajaran yang bersifat mendidik dan menekankan pentingnya masalah kontekstual untuk memperkenalkan topik-topik matematika kepada peserta didik. d) Membangun sendiri model (Self-developed model); Prinsip ketiga ini menunjukkan adanya fungsi "jembatan" yang berupa model.

Prinsip utama PMR dijabarkan menjadi karakteristik PMR. Karakteristik PMR menurut Wijaya (2012), Treffers (2012), Ningsih (2014), Ramadhani \& Caswita (2017)), Isrok'atun (2018), Soedjadi (2001) dan Rahmawati (2013)adalah: 1) mengawali pembelajaran matematika dengan masalah nyata, 2) menggunakan model sebagai suatu jembatan antara real dan abstrak yang dapat membantu siswa belajar matematika pada level abstraksi, 3) menggunakan kontribusi siswa sendiri atau strategi sebagai hasil dari mereka, (doing mathematic). 4) memaksimalkan interaksi antara siswasiswa, siswa- guru, dan siswa-sumber belajar. 5) mengaitkan materi matematika dengan topik matematika lainya (intertwin).

Karakteristik utama PMR dapat dijabarkan menjadi langkah-langkah dalam pembelajaran. Rahmawati (2013), dan Widyastuti \& Pujiastuti (2014) menyimpulkan langkah-langkah penerepan pembelajaran PMR sebagai berikut: a) memahami masalah kontekstual; b) menjelaskan masalah kontekstual, c) menyelesaikan masalah kontekstual, d) Mendiskusikan penyelesaian masalah dan membandingkan; e) menyimpulkan materi pembelajaran.

Pendekatan PMR yang diterapkan dalam proses pembelajaran memiliki manfaat dalam kemampuan matematis berdasarkan penelitian, diantaranya: meningkatkan kemampuan pemecahan masalah matematis; Muchlis (2012), D. Rahmawati \& Putri (2015) menyimpulkan bahwa kemampuan pemecahan masalah matematika siswa yang belajar dengan pendekatan PMR lebih baik secara signifikan dari pada siswa yang belajar dengan pendekatan konvensional.

Dalam rangka implementasi pendekatan PMR dalam pembelajaran perlu dukungan ketersedian perangkat pembelajaran yang sesuai dalam kaedah PMR. Terkait dengan ketersediaan perangkat tersebut, hasil wawancara dan observasi yang peneliti lakukan mengenai perangkat pembelajaran yang digunakan, diperoleh informasi dari lima orang guru SD di kota Pekanbaru menunjukkan bahwa 20\% guru menggunakan perangkat pembelajaran yang dikembangkan sendiri dalam proses pembelajaran, sedangkan $80 \%$ tidak mengembangkan perangkat pembelajaran atau menggunakan perangkat yang sudah ada. Perangkat pembelajaran yang sudah ada berasal dari penerbit atau Kelompok Kerja Guru (KKG). Guru yang telah mengembangkan perangkat pembelajaran mampu menyusun perangkat pembelajaran sesuai dengan kaidah dalam kurikulum 2013.

Hasil wawancara lebih lanjut menunjukkan bahwa guru kesulitan dalam menyusun perangkat pembelajaran. Guru belum sepenuhnya memahami esensi dari masing-masing komponen dari RPP, seperti mengembangkan indikator pencapaian kompetensi yang mengacu pada $\mathrm{KD}$, merumuskan tujuan pembelajaran, dan mengembangkan kegiatan pembelajaran dengan menerapkan model atau pendekatan yang memfasilitasi peserta didik untuk berpartisipasi aktif dalam proses pembelajaran. 
Memperhatikan kondisi perangkat pembelajaran yang digunakan guru dan kegunaaan pendekatan PMR maka peneliti mencoba mengembangkan perangkat pembelajaran dengan pendekatan PMR. Perangkat pembelajaran yang tepat merupakan faktor penting dalam pembelajaran. Dalam rangka menghasilkan perangkat pembelajaran yang berkualitas diperlukan pengembangan perangkat pembelajaran secara bertahap dan terus-menerus melewati berbagai tahapan uji coba dan revisi (Agustina Fatmawati, 2016). Tiga kriteria yang harus dipenuhi agar perangkat pembelajaran dikatakan berkualias meliputi kevalidan, kepraktisan, dan keefektifan (Zulfiah, 2017). Berdasarkan permasalahan diatas, maka peneliti akan mengembangakan perangkat pembelajaran matematika yang memenuhi kriteria valid dan praktis melalui pendekatan PMR pada materi keliling dan luas bangun datar peserta didik kelas IV SD.

\section{METODE}

Penelitian ini merupakan penelitian pengembangan (research and development) dengan model 4-D. Produk dari penelitian pengembangan ini adalah perangkat pembelajaran menggunakan pendekatan pendidikan matematika realistik untuk peserta didik SD/MI kelas IV. Perangkat yang dikembangkan yaitu silabus, Rencana Pelaksanaan Pembelajaran (RPP) dan Lembar Kegiatan Peserta Didik (LKPD). Penelitian dilaksanakan pada bulan Mei 2020 di SD Islam Plus YLPI Pekanbaru. Subjek uji coba dalam penelitian ini adalah dosen ahli dan peserta didik kelas IV. Subjek uji coba kelompok kecil dipilih secara acak sebanyak 8 orang peserta didik kelas IV dengan kemampuan akademis yang heterogen. Prosedur pengembangan dalam penelitian ini hanya sampai tiga tahapan karena terbatasnya waktu untuk mengumpulkan peserta didik (pandemi Covid-19), adapun tahapannya terdiri atas pendefinisian (define), perancangan (design), dan pengembangan (develop).

Pada tahap pendefinisian (define), dilakukan beberapa kegiatan pendefinisian sebagai acuan perancangan produk awal, yaitu: 1) analisis awal-akhir, bertujuan menganalisis permasalahan secara mendasar terhadap pembelajaran matematika dikelas dan penentuan alternatif solusi pemecahan masalah, 2) analisis peserta didik yang ditinjau dari karakteristik serta kemampuan akademik peserta didik, 3) analisis tugas, menganalisis tugas-tugas pokok yang harus dikuasi peserta didik yang berkaitan dengan materi pembelajaran, KD dan merumuskan IPK sehingga mencapai kompetensi minimal, 4) Analisis konsep, mengidentifikasi konsep pokok yang akan diajarkan, 5) Spesifikasi tujuan pembelajaran, merangkum hasil dari analisis tugas dan konsep untuk menentukan perilaku objek penelitian.

Pada tahapan rancangan (design) dilakukan beberapa kegiatan perancangan yaitu 1) Pemilihan media, bertujuan menentukan media yang tepat untuk materi pembelajaran berdasarkan karakteristik materi, karakteristik peserta didik dan analisis tugas, 2) Pemilihan format, berdasarkan media pembelajaran yang digunakan, 3) Rancangan awal, merancang perangkat pembelajaran berupa silabus, RPP, LKPD dan soal kemampuan pemecahan masalah matematis berdasarkan format yang telah 
dibuat. Pada tahap pengembangan (development) peneliti melakukan tiga kegiatan yaitu mengembangkan perangkat pembelajaran, dilakukan uji coba ahli (validasi), dan uji coba kelompok kecil. Perangkat pembelajaran yang telah dikembangkan selanjutnya divalidasi. Uji ahli dilakukan untuk menentukan kevalidan dari hasil rancangan awal perangkat pembelajaran. Perangkat pembelajaran yang telah divalidasi kemudian direvisi berdasarkan saran dari validator dan dilakukan uji coba kelompok kecil untuk mengetahui ke praktisan dari LKPD yang dikembangan.

Teknik pengumpulan data dalam penelitian ini terdiri atas dua jenis, yaitu lembar penilaian perangkat pembelajaran dan angket respon peserta didik. lembar penilaian perangkat pembelajaran dilakukan dengan memberikan lembar validasi silabus, lembar validasi RPP, lembar validasi LKPD, dan lembar validasi tes KPMM digunakan untuk mengukur kevalidan perangkat pembelajaran, sedangkan angket respon peserta didik digunakan untuk mengetahui respon peserta didik dan kepraktisan penggunaan LKPD yang dikembangkan.

Analisis data dilakukan untuk mengetahui kevalidan dan kepraktisan dari perangkat pembelajaran yang dikembangkan. Data hasil validasi ahli dianalisis untuk mengetahui aspek kevalidan perangkat. Perangkat pembelajaran dikatakan valid jika hasil analisis yang telah dilakukan rata-rata memenuhi kategori valid. Analisis kevalidan perangkat pembelajaran menggunakan indeks validitas Sa'dun Akbar.

Analisis keterbacaan dan kepraktisan bertujuan untuk mengetahui apakah perangkat pembelajaran yang dikembangkan memenuhi kriteria kepraktisan. Kepraktisan perangkat dianalisis berdasarkan data yang diperoleh dari penilaian peserta didik pada uji coba kelompok kecil. Sa'dun Akbar (2013) menyatakan perangkat pembelajaran dikatakan praktis jika kategori dari hasil analisis setiap perangkat minimal praktis.

Adapun kriteria validitas perangkat pembelajaran dari validator dan praktikalitas perangkat pembelajaran dari pengguna dapat dilihat pada Tabel 2.

\section{Tabel 2.}

Kriteria validitas dan Praktikalitas

\begin{tabular}{|c|c|c|}
\hline No & Tingkat Pencapaian & Tingkat Validitas dan Praktikalitas \\
\hline 1 & $85,01 \%-100,00 \%$ & Sangat praktis \\
\hline 2 & $70,01 \%-85,00 \%$ & Praktis \\
\hline 3 & $50,01 \%-70,00 \%$ & Kurang praktis \\
\hline 4 & $01,00 \%-50,00 \%$ & Tidak praktis \\
\hline
\end{tabular}

Menurut Sa'dun Akbar (2013), perangkat pembelajaran dikatakan valid dapat digunakan jika persentase validasi dan kepraktisan lebih dari $70 \%$. 


\section{HASIL}

Pada penelitian ini menghasilkan perangkat pembelajaran berupa silabus, RPP, dan LKPD untuk peserta didik SD kelas IV pada materi luas dan keliling bangun datar. Perangkat ini dikembangkan menggunakan pendekatan pendidikan matematika. Perangkat pembelajaran yang peneliti kembangkan ini dirancang menggunakan model 4-D dengan empat tahapan yaitu tahap define (pendefinisian), tahap design (perancangan), tahap develop (pengembangan), tahap disseminate (penyebaran). Namun, pada penelitian ini, tahap develop (pengembangan) yang peneliti lakukan hanya sampai pada ujicoba kelompok kecil untuk melihat kepraktisan perangkat pembelajaran yang dikembangkan.

Pada tahap define (pendefinisian) terdiri dari analisis awal-akhir, analisis peserta didik, analisis tugas, analisis konsep, dan spesifikasi tujuan pembelajaran. 1) Pada tahap analisis awal-akhir peneliti melakukan analisis terhadap perangkat pembelajaran yang digunakan guru disekolah. Analisis dilakukan dengan teknik wawancara terhadap lima orang guru matematika kelas IV. Berdasarkan hasil wawancara yang peneliti lakukan dapat disimpulkan bahwa sebagian besar guru belum mengembangkan perangkat pembelajaran secara mandiri, indikator pencapaian kompetensi belum dapat mengukur ketercapaian $\mathrm{KD}$, tujuan pembelajaran belum dapat mengukur ketercapaian $\mathrm{KD}$, lembar kerja belum dapat memfasilitasi peserta didik untuk menemukan pengetahuan, alokasi waktu 4 pertemuan belum sesuai dengan ketercapaian KD. 2) Pada analisis peserta didik berdasarkan hasil pra penelitian menunjukkan kemampuan pemecahan masalah matematis peserta didik pada materi keliling dan luas bangun datar masih tergolong rendah. Dari hasil analisis jawaban peserta didik tersebut, didapat bahwa peserta didik dapat menuliskan apa yang diketahui namun masih kurang jelas dan tidak lengkap dalam menguraikannya. Urutan langkah rencana pemecahan masalah tidak terurut dengan baik dan tidak lengkap. Peserta didik tampak belum mampu menyelesaikan rencana pemecahan masalah. Peserta didik tidak menuliskan kesimpulan jawaban. Jika dikaitkan dengan tahap perkembangan kognitif, menurut Piaget peserta didik kelas IV berusia 9-10 tahun, ini berada pada tahap perkembangan operasional konkret Oleh karena itu, sangat tepat bila pembelajaran matematika diawali dengan masalah kontekstual yang dekat dengan kehidupan sehari-hari. 3) Analisis tugas yang peneliti lakukan meliputi analisis terhadap kompetensi inti (KI) dan kompetensi dasar (KD) yang sesuai dengan materi yang akan dikembangkan. Analisis tugas dilakukan dengan cara menelaah dokumen dan studi literatur terhadap KI dan KD yang akan dikembangkan. Hasil ini dijadikan sebagai acuan dalam menentukan materi yang mendukung tercapai kompetensi. Peneliti menganalisis tugas-tugas pokok yang harus dikuasai peserta didik agar peserta didik dapat mencapai kriteria ketuntasan minimal (KKM). Peneliti menganalisis tugas pokok pada materi pembelajaran berupa aktivitas peserta didik untuk menemukan konsep materi, dalam hal ini aktivitas proses pembelajaran tercantum pada LKPD. 4) Pada tahap analisis konsep peneliti mengidentifikasi konsep materi yang akan dikembangkan. Pada penelitian ini materi yang akan peneliti kembangkan adalah 
materi keliling dan luas bangun datar. Berdasarkan analisis konsep yang peneliti lakukan maka materi keliling dan luas bangun datar ini terdiri dari keliling persegi, luas persegi, keliling persegi panjang, luas persegi panjang, keliling segitiga, dan luas segitiga, untuk 6 kali pertemuan dengan menggunakan pendekatan pendidikan matematika realistik. 5) Spesifikasi tujuan pembelajaran, peneliti merumuskan tujuan pembelajaran yang memuat komponen $\mathrm{ABCD}$ yang dapat mengukur ketercapaian KD.

Pada tahap design (perancangan) peneliti melakukan kegiatan diantaranya memilih media dan format untuk perangkat pembelajaran matematika yang dikembangkan berupa Silabus, RPP dan LKPD, selanjutnya peneliti mendesain rancangan awal yang sesuai dengan format yang telah dipilih. Silabus dan RPP dirancang berpedoman pada komponen silabus dan RPP yang terdapat pada Permendikbud Nomor 22 tahun 2016.

Hasil analisis perangkat pembelajaran menunjukkan silabus yang dirancang terdiri dari komponen $\mathrm{KD}$, materi pembelajaran, dan kegiatan pembelajaran untuk enam pertemuan pada materi keliling dan luas bangun datar yang memuat komponen identitas, KI, KD, materi pembelajaran, indikator pencapaian kompetensi, kegiatan pembelajaran, penilaian, alokasi waktu, dan sumber belajar. Peneliti merancang RPP pada materi keliling dan luas bangun datar untuk enam kali pertemuan yang masing-masing memuat komponen identitas; KI; KD dan indikator pencapaian kompetensi; tujuan pembelajaran; materi pembelajaran; pedekatan, model, dan metode pembelajaran; media, alat, dan sumber belajar; langkah-langkah pembelajaran; dan penilaian. Peneliti merancang LKPD dengan menerapkan pendekatan PMR, sehingga dapat memfasilitasi peserta didik dalam melakukan penyelidikan yang terdiri dari bagian sampul, isi LKPD dan latihan soal awal berisi sampul LKPD, bagian isi berisi lembar aktivitas, dan bagian kesimpulan/ akhir berisi latihan soal .

Pada tahap develop (pengembangan) perangkat pembelajaran yang sudah di rancang berdasarkan format kemudian dikembangkan Kegiatan pembelajaran pada silabus dan RRP disusun lebih rinci dengan menguraikan secara lebih jelas tentang langkah-langkah pendekatan pendidikan matematika realistik yaitu memahami masalah kontekstual, menjelaskan masalah kontekstual, menyelesaikan masalah kontekstual, mendiskusikan dan membandingkan jawaban, dan membuat kesimpulan. Berikut contoh kegiatan pembelajaran pada silabus dan RPP yang telah dikembangkan.

\begin{tabular}{|c|c|c|c|c|}
\hline Kompetensi Dasar & $\begin{array}{l}\text { Materi Pokok/ } \\
\text { Materi } \\
\text { Pembelajaran }\end{array}$ & Indikator Percapaian Kompetensi & Kegiatan Pembelajaran & Penilaian \\
\hline $\begin{array}{l}\text { 3.9. Menjelaskan dan } \\
\text { menentukan keliling dan luas } \\
\text { daerah persegi, persegi } \\
\text { panjang, dan segitiga } \\
\text { 4.9. Menvelesaikan masalah } \\
\text { berkaitan dengan keliling dan } \\
\text { luas daerah persegi, persegi } \\
\text { panjang, dan segitiga }\end{array}$ & I. Keliling persegi & $\begin{array}{ll}\text { 3.9.1 } & \begin{array}{l}\text { Mengidentifikasi sifat - sifat } \\
\text { bangun datar persegi }\end{array} \\
\text { 3.9.2. } & \begin{array}{l}\text { Menemukan rumus keliling } \\
\text { persegi }\end{array} \\
\text { 3.9.3 } & \text { Menentukan keliling persegi } \\
\text { 4.9.1 } & \begin{array}{l}\text { Menghasilkan keliling } \\
\text { persegi dari masalah } \\
\text { kontekstual }\end{array}\end{array}$ & 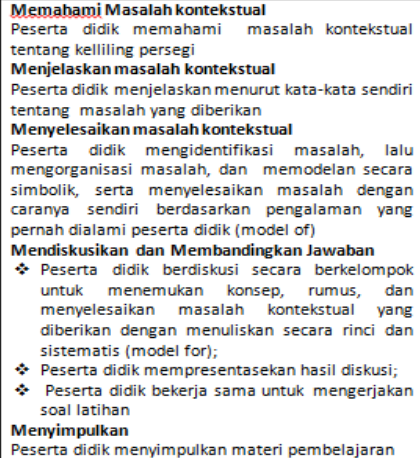 & $\begin{array}{l}\text { Pengetabuan: } \\
\text { 1. Tes tertulis (soal } \\
\text { uraian) pada akhir } \\
\text { pembelajaran dan } \\
\text { 2. Tes lisan (tanya } \\
\text { jawab sabelama } \\
\text { pembelajaran } \\
\text { berlangsung, } \\
\text { 3. Penugasan (hasil } \\
\text { tugas individu dan } \\
\text { kelompok). } \\
\text { Keterampilan: } \\
\text { Renilaian kineria } \\
\text { dalam menentukan } \\
\text { rumous kelililing persegi }\end{array}$ \\
\hline
\end{tabular}

Gambar 1. Gambaran Silabus 


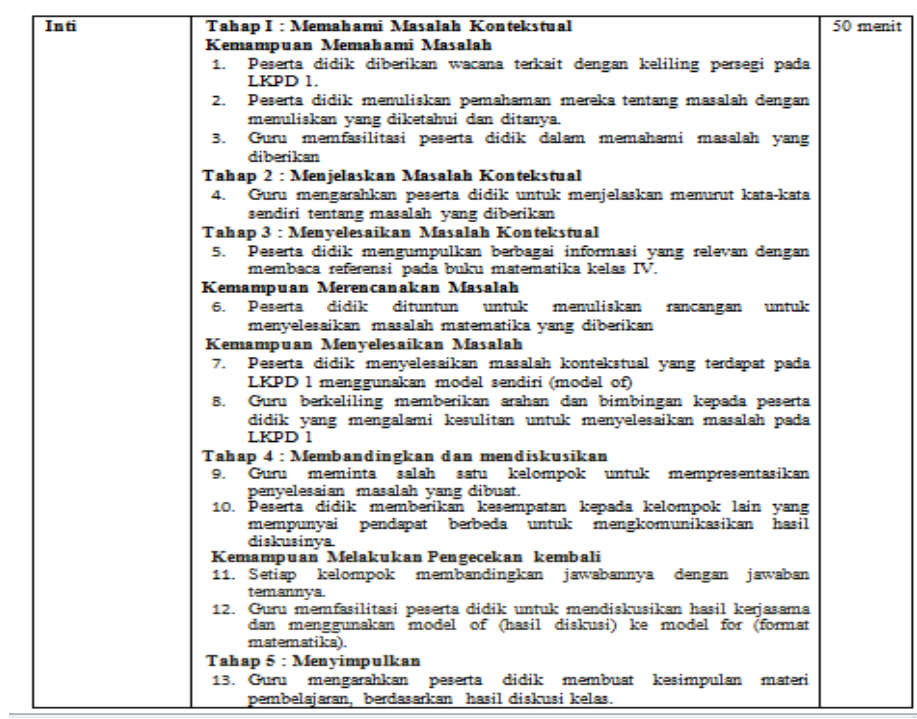

Gambar. 2 Gambaran Kegiatan Inti Pada RPP

LKPD dikembangkan berdasarkan langkah pendekatan PMR dan indikator kemampuan pemecahan masalah matematis. Hasil rancangan LKPD terdiri dari sampul, isi LKPD dan latihan soal. Sampul LKPD dirancang memuat judul, kotak penulisan nama, petunjuk dan tujuan pembelajaran. Sampul LKPD juga dihiasi dengan gambar yang sesuai dengan materi pelajaran. Bagian sampul LKPD dibuat dengan tampilan yang sama, namun dengan warna dan gambar yang berbeda. Bagian isi LKPD disusun berdasarkan langkah-langkah pendekatan PMR yaitu memahami masalah kontekstual, menjelaskan masalah kontekstual, menyelesaikan masalah kontekstual, mendiskusikan dan membandingkan jawaban, dan membuat kesimpulan dan indikator kemampuan pemecahan masalah matematis. Pada bagian isi LKPD dirancang dengan kegiatan yang sama, namun disesuaikan dengan materi yang dipelajari untuk setiap pertemuannya. Berikut ini contoh bagian sampul dan bagian isi LKPD yang telah dikembangkan.

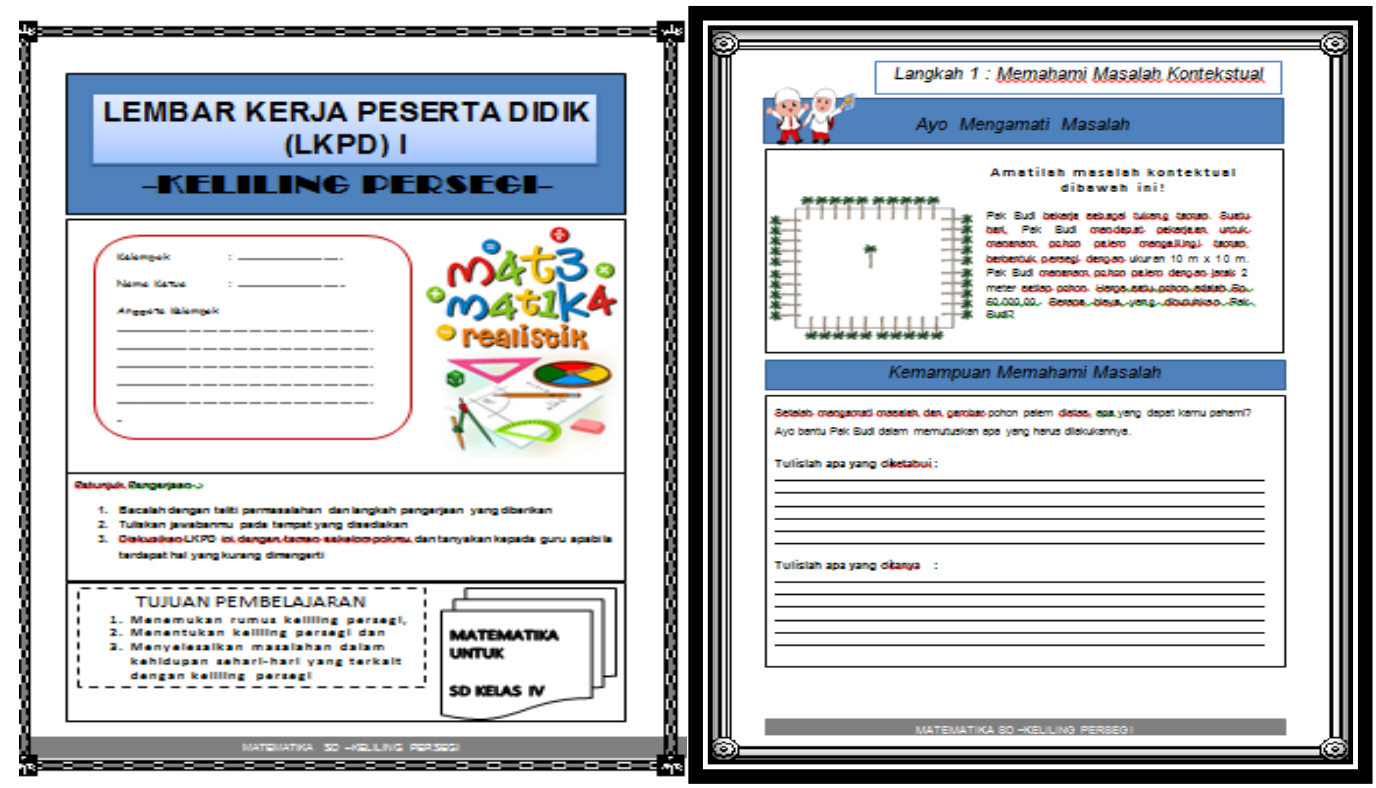

Gambar 3. Bagian Sampul dan Langkah Memahami Masalah 
Rancangan LKPD pada Gambar 3 merupakan rancangan bagian sampul dan bagian isi LKPD yaitu langkah memahami masalah pada materi keliling persegi. Pada langkah memahami masalah diberikan sebuah permasalahan dalam kehidupan sehari-hari yang berbentuk soal cerita. Pada Langkah memahami masalah kontekstual, peserta didik memahami masalah kontekstual yang disajikan berupa kolom "ayo mengamati masalah" terkait dengan keliling persegi kemudian menuangkan pemahaman mereka tentang masalah dengan menuliskan yang diketahui dan ditanya. Guru memfasilitasi peserta didik dalam memahami masalah yang diberikan.

Langkah menjelaskan masalah kontekstual, peserta didik diarahkan untuk menjelaskan menurut kata-kata sendiri tentang masalah yang diberikan di dalam kolom "ayo menjelaskan". Langkah menyelesaikan masalah kontekstual, pada langkah ini peserta didik diawali dengan tahap mengumpulkan informasi pada buku matematika kelas IV dan uraian yang disediakan dalam kolom "ayo mengumpulkan informasi" kolom ini disajikan sebagai fasilitas bagi peserta didik untuk menemukan pengetahuan yang dapat digunakan untuk menyelesaikan masalah. Tahap selanjutnya yaitu membuat rencana pemecahan masalah dan kemampuan menyelesaikan masalah, berdasarkan informasi yang telah didapat peserta didik kemudian menuangkan rencana pemecahan berupa langkah-langkah penyelesaian masalah menggunakan model sendiri (model of).

Langkah membandingkan dan mendiskusikan, peserta didik selanjutnya mempresentasikan hasil diskusinya, bagi kelompok yang mempunyai pendapat yang berbeda untuk dapat menkomunikasikan sehingga menuju format matematika (model for) di dalam kolom ayo berdiskusi. Langkah selanjutnya menyimpulkan, dengan bimbingan guru peserta didik menemukan rumus keliling persegi dengan format matematika. Adapun rancangan kolom ayo menyimpulkan Pada LKPD yang dirancang juga disajikan ayo berlatih sebagai latihan formatif bagi peserta didik setelah menyelesaikan permasalahan yang diberikan pada awal LKPD.

Perangkat pembelajaran yang sudah dikembangkan di validasi kepada validator serta melakukan uji coba terhadap perangkat yang telah disusun. Saran-saran dari validator tersebut akan dijadikan bahan untuk merevisi perangkat yang telah disusun. Hasil revisi tersebut merupakan perangkat pembelajaran yang telah memenuhi kriteria valid. Perangkat pembelajaran yang telah dinyatakan valid diuji coba terhadap peserta didik. Pada penelitian ini, uji coba dilakukan hanya sampai pada uji coba kelompok kecil untuk melihat kepraktisan perangkat pembelajaran yang dikembangkan. Uji coba ini dilakukan terhadap 8 orang peserta didik kelas IV SD Islam Plus YLPI Pekanbaru. Rata-rata penilaian yang diberikan oleh tiga orang validator terhadap perangkat pembelajaran yang dikembangkan berupa silabus, RPP dan LKPD serta soal dapat dilihat pada Tabel 3 s/d Tabel 6 berikut. 


\section{Tabel 3.}

Hasil Validasi Silabus

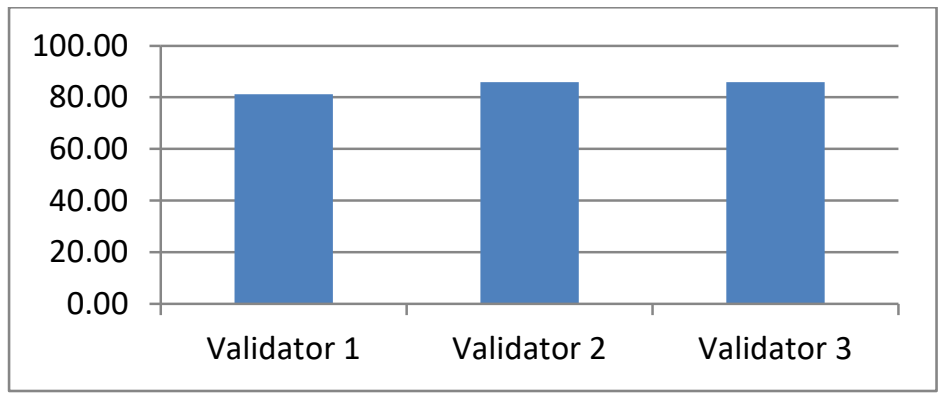

Sumber: Olahan data, 2020

Dari Tabel 3 di atas diperoleh bahwa rata-rata keseluruhan terhadap penilaian silabus sebesar 88,54 dengan kriteria "sangat valid". Ketiga validator menyimpulkan bahwa silabus dapat digunakan, akan tetapi validator tetap memberikan masukan dan saran agar silabus yang dikembangkan lebih baik lagi. Penilaian dari validator berupa koreksi, kritik, dan saran yang digunakan sebagai bahan pertimbangan dalam melakukan revisi silabus.

\section{Tabel 4.}

\section{Hasil Validasi RPP}

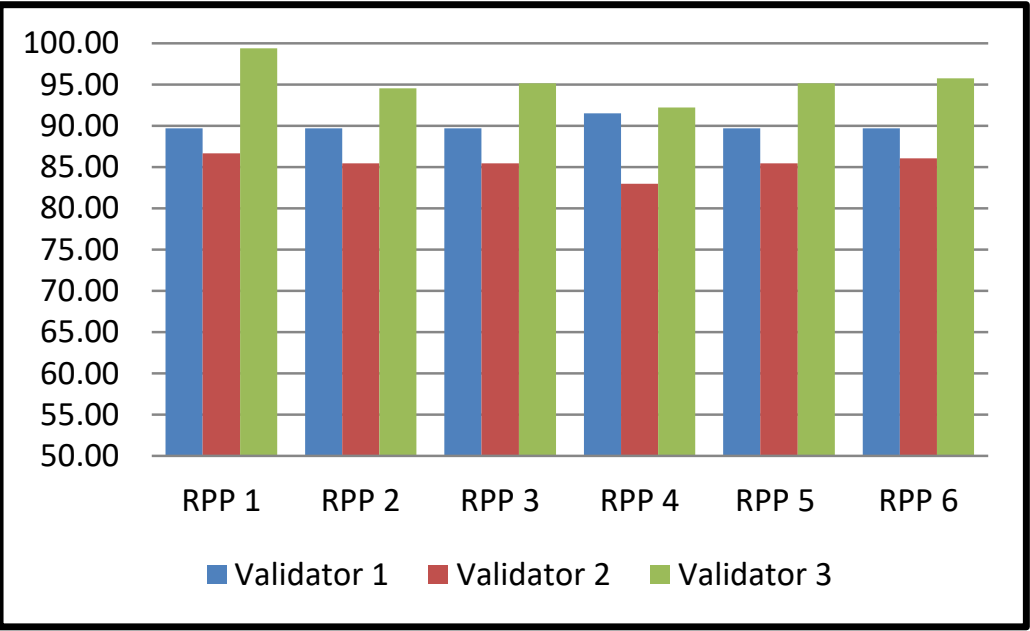

Sumber: Olahan data, 2020

Pada Tabel 4 diperoleh skor rata-rata keseluruhan terhadap penilaian RPP sebesar 90,57 dengan kriteria "sangat valid". Ketiga validator menyimpulkan bahwa RPP dapat digunakan, akan tetapi validator tetap memberikan masukan dan saran agar RPP yang dikembangkan lebih baik lagi. Penilaian dari validator berupa koreksi, kritik, dan saran yang digunakan sebagai bahan pertimbangan dalam melakukan revisi RPP. Saran dari validator terhadap RPP yang dikembangkan yaitu identitas pada silabus sebaiknya dilengkapi dengan mencantumkan nama sekolah tempat penelitian, simbol yang digunakan pada materi pembelajaran sebaiknya konsisten, apersepsi sebaiknya diuraikan secara 
jelas, pada kegiatan inti sebaiknya disampaikan dalam RPP kegiatan apa saja yang dilakukan oleh peserta didik, selanjutnya redaksi soal pada RPP lebih diperjelas.

\section{Tabel 5.}

\section{Hasil Validasi LKPD}

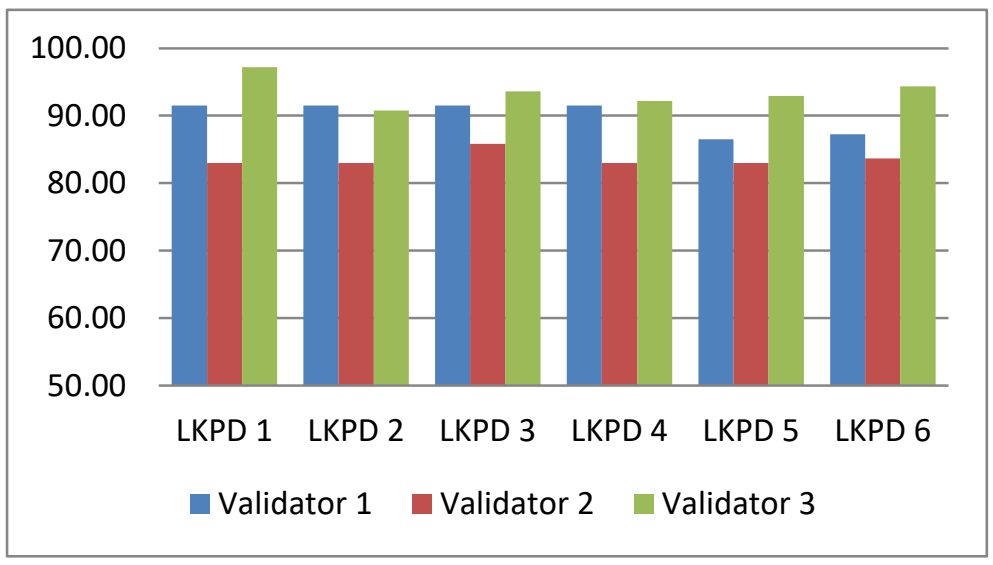

Sumber: Olahan data, 2020

Dari Tabel 5 diperoleh rata-rata skor keseluruhan terhadap penilaian LKPD sebesar 89,01 dengan kriteria "sangat valid". Ketiga validator menyimpulkan bahwa LKPD dapat digunakan, akan tetapi validator tetap memberikan masukan dan saran agar LKPD yang dikembangkan lebih baik lagi. Penilaian dari validator berupa koreksi, kritik, dan saran yang digunakan sebagai bahan pertimbangan dalam melakukan revisi LKPD. Saran dari validator untuk LKPD yang dikembangkan yaitu pada sampul LKPD sebaiknya ditambahkan alokasi waktu agar peserta didik dapat memaksimalkan waktu selama proses pembelajaran. Pada kegiatan mengumpulkan sebaiknya diberikan alat peraga, gambar yang diberikan pada permasalahan dalam LKPD sebaiknya diperjelas agar peserta didik dapat memahami masalah tersebut, selanjutnya redaksi soal pada awal LKPD sebaiknya lebih diperjelas.

\section{Tabel 6.}

\section{Hasil Validasi Soal}

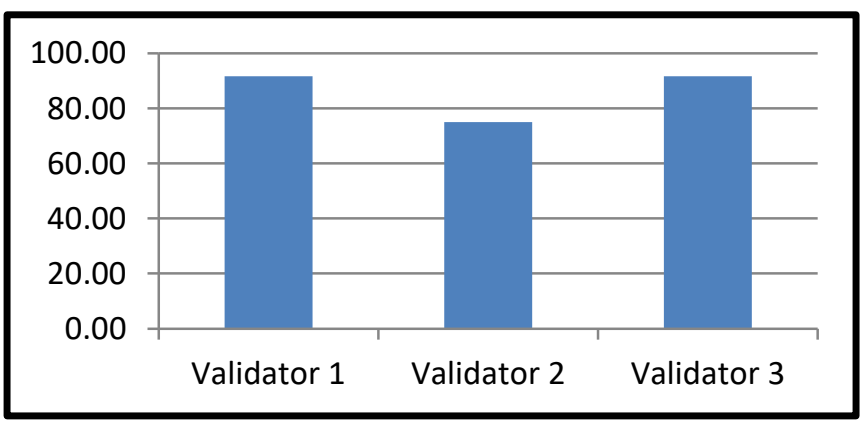

Sumber: Olahan data, 2020

Dari Tabel 6, diperoleh bahwa rata-rata skor keseluruhan terhadap penilaian soal 89,58 dengan kriteria "sangat valid". Ketiga validator menyimpulkan bahwa soal dapat digunakan dengan revisi. 
Penilaian dari validator berupa koreksi, kritik, dan saran yang digunakan sebagai bahan pertimbangan dalam melakukan revisi soal. Setelah memenuhi kriteria valid, perangkat pembelajaran dilakukan uji kepraktisan melalui ujicoba kelompok kecil. Pada penelitian ini, uji coba dilakukan terhadap 8 orang peserta didik kelas IV SD Islam Plus YLPI.Se Pekanbaru. Selanjutnya, kedelapan orang peserta didik diminta untuk mengisi angket respon peserta didik setelah selesai mengerjakan LKPD. Hasil lengkap angket respon peserta didik dari uji coba kelompok kecil dapat dilihat pada Tabel 7 berikut:

\section{Tabel 7.}

Hasil Angket Respon Peserta Didik Uji Coba Kelompok Kecil

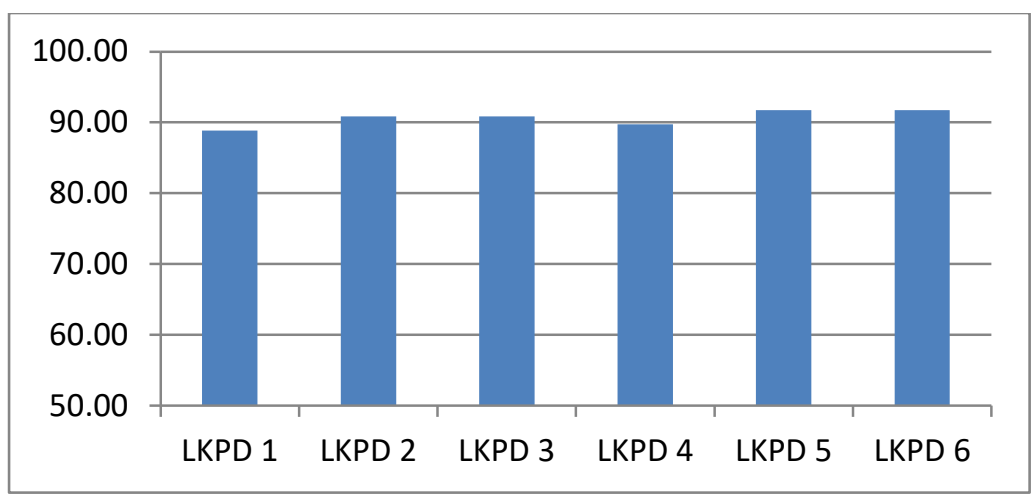

Sumber: Olahan data, 2020

Pada Tabel 7 rata-rata kepraktisan LKPD pada uji coba kelompok kecil adalah 90,63 Berdasarkan Tabel 7 kriteria penilaian kepraktisan LKPD memenuhi kriteria "sangat praktis". LKPD yang dikembangkan bisa digunakan untuk uji coba kelompok besar, Artinya LKPD sudah dapat dipahami oleh peserta didik dari segi masalah yang diberikan, kalimat perintah dalam melakukan kegiatan dan soal latihan, LKPD sudah dapat dikerjakan oleh peserta didik dengan baik. LKPD sudah menggambarkan pendekatan PMR, dimana peserta didik menemukan sendiri rumus keling dan luas bangun datar.

\section{KESIMPULAN}

Berdasarkan hasil penelitian dan pengembangan yang telah diuraikan diperoleh beberapa simpulan. (1) Produk perangkat pembelajaran matematika menggunakan pendekatan PMR untuk peserta didik kelas IV semester genap memiliki karakteristik : a) mengawali pembelajaran matematika dengan masalah nyata, b) menggunakan model sebagai suatu jembatan antara real dan abstrak yang dapat membantu siswa belajar matematika pada level abstraksi, c) menggunakan kontribusi siswa sendiri atau strategi sebagai hasil dari mereka, (doing mathematic). d) memaksimalkan interaksi antara siswa- siswa, siswa- guru, dan siswa-sumber belajar. e) mengaitkan materi matematika dengan topik matematika lainya (intertwin). f) mengembangkan KPMM peserta didik. (2) Produk akhir perangkat pembelajaran memenuhi kriteria kevalidan dengan skor rata-rata penilaian validator pada kategori sangat valid. (3) Produk akhir perangkat pembelajaran memenuhi kriteria praktis dengan 
rata-rata penilaian peserta didik pada kategori sangat praktis.

\section{DAFTAR PUSTAKA}

Agustina Fatmawati. (2016). Pengembangan Perangkat Pembelajaran Konsep Pencemaran Lingkungan Menggunakan Model Pembelajaran Berdasarkan Masalah untuk SMA Kelas X. Jurnal EduSains UIN Jakarta, 4.

Apriyani, Sehatta Saragih, dan Y. R. (2018). THE LEARNING INSTRUMENT DEVELOPMENT OF PROBLEM BASED LEARNING MODEL TO DEVELOP THE MATHEMATICAL PROBLEM SOLVING ABILITY ON THE CURVED SIDES SPACE SUBJECT FOR 9 TH GRADE STUDENTS PENGEMBANGAN PERANGKAT PEMBELAJARAN MODEL PROBLEM BASED LEARNING UNTUK MENGEM. Jurnal Online Mahasiswa, 5, 1-12.

Daitin Tarigan. (2006). Pembelajaran Matematika Realistik. Jakarta: Buku Rujukan PGSD Bidang Matematika.

Heleni, S., \& Zulkarnain, Z. (2018). The Influence of Mathematical Thinking Ability with Modified MOORE Method on Learning Outcomes of Basic Mathematic II Chemical Education Students. Journal of Educational Sciences, 2(2), 33-41.

Heruman. (2014). Model Pembelajaran Matematika di Sekolah Dasar. Bandung: PT Remaja Rosdakarya.

Isrok'atun, R. A. (2018). Model-Model Pembelajaran Matematika. Jakarta: PT. Bumi Aksara.

Kementerian Pendidikan dan Kebudayaan. (2017). Impelementasi Pengembangan Kecakapan Abad 21 dalam Perencanaan Pelaksanaan Pembelajaran (RPP). Jakarta: Direktorat Jenderal Pendidikan Dasar dan Menengah.

Muchlis, E. E. (2012). Pengaruh Pendekatan Pendidikan Matematika Realistik Indonesia ( PMRI ) Terhadap Perkembangan Kemampuan Pemecahan Masalah Siswa Kelas II SD Kartika 1 . 10 Padang. Jurnal Exacta, X(2), 136-139. Retrieved from http://repository.unib.ac.id/519/1/08. Effie Efrida Mukhlis.pdf

Ningsih, S. (2014). Realistic Mathematics Education: Model Alternatif Pembelajaran Matematika Sekolah. Jurnal Pendidikan Matematika, 1(2), 73-94.

Pal, A., \& Poyen, E. F. Bin. (2017). Problem solving approach. International Journal of Advanced Engineering Research and Science, 4(5), 237180.

Rahmawati, D., \& Putri, A. D. (2015). KEEFEKTIFAN PEMBELAJARAN DENGAN PENDEKATAN PENDIDIKAN MATEMATIKA REALISTIK (PMRI) PADA KEMAMPUAN PEMECAHAN MASALAH POKOK BAHASAN SEGIEMPAT DI MTS NEGERI 1 PALEMBANG. Jurnal Pendidikan Matematika RAFA, 1(1), 1-20.

Rahmawati, F. (2013). Pengaruh Pendekatan Pendidikan Realistik Matematika dalam Meningkatkan Kemampuan Komunikasi Matematis Siswa Sekolah Dasar. Prosiding SEMIRATA 2013, 1(1).

Ramadhani, M. H., \& Caswita, C. (2017). PEMBELAJARAN REALISTIC MATHEMATIC EDUCATION TERHADAP KEMAMPUAN BERPIKIR KREATIF. In Prosiding Seminar Nasional Matematika dan Pendidikan Matematika (Vol. 1, pp. 265-272).

Ratnasari, D. R., \& Ratu, N. (2017). DESKRIPSI PEMECAHAN MASALAH PADA MATERI ARITMATIKA SOSIAL BERDASARKAN TEORI POLYA BAGI SISWA KELAS VIII SMP N 3 SALATIGA. In SEMINAR NASIONAL ALFA VII.

Sa'dun Akbar. (2013). Instrumen Perangkat Pembelajaran. Bandung: remaja rosdakarya.

Soedjadi, R. (2001). Pembelajaran Matematika Berjiwa RME. In Makaiah Seminar Nasional tentang Pendidikan Matematika Realistik di USD Yogyakarta tanggal (pp. 14-15).

Sugianto, Roza, Y., \& M. (2020). Journal of Educational Sciences, 4(3), 668-678.

Sundayana, R. (2016). Kaitan antara gaya belajar, kemandirian belajar, dan kemampuan pemecahan masalah siswa SMP dalam pelajaran matematika. Mosharafa: Jurnal Pendidikan Matematika, $5(2), 75-84$.

Susana, D., \& Zubir, A. (2015). Penerapan Pendekatan Pendidikan Matematika Realistik (PMR) Terhadap Kemampuan Pemecahan Masalah Matematika Siswa SMP Negeri 1 Sungai Penuh. Jurnal Penelitian Universitas Jambi: Seri Humaniora, 17(1), 43490.

Treffers, A. (2012). Three dimensions: A model of goal and theory description in mathematics 
instruction-The Wiskobas Project (Vol. 3). Springer Science \& Business Media.

Van den Heuvel-Panhuizen, M. (1996). Assessment and realistic mathematics education (Vol. 19). Utrecht University.

Widyastuti, N. S., \& Pujiastuti, P. (2014). Pengaruh pendidikan matematika realistik indonesia (PMRI) terhadap pemahaman konsep dan berpikir logis siswa. Jurnal Prima Edukasia, 2(2), 183-193.

Wijaya, A. (2012). Pendidikan matematika realistik suatu alternatif pendekatan pembelajaran matematika. Yogyakarta: Graha Ilmu.

Zulfiah, A. (2017). PENGEMBANGAN PERANGKAT PEMBELAJARAN, 34, 105-112. 